\title{
Liver Cells Apoptosis Biomarkers among Egyptian Patients with Chronic Hepatitis-C Virus and Hepatocellular Carcinoma
}

\author{
Zahran Faten ${ }^{1 *}$, El- Emshaty Hoda ${ }^{2}$, Gouida Mona ${ }^{3}$ and Hussien Mohamed ${ }^{4}$ \\ ${ }^{1}$ Biochemistry Division, Zagazig University, Egypt \\ ${ }^{2}$ Gastroenterology Center, Mansoura University, Egypt \\ ${ }^{3}$ Mansoura Children Hospital, Mansoura University, Egypt \\ ${ }^{4}$ Mansoura Chest Hospital, Egypt
}

Submission: March 11, 2017; Published: May 03, 2017

*Corresponding author: Faten Zahran, Biochemistry Division, Faculty of Science, Zagazig University, Egypt, Email: dr_fzahran@yahoo.com

\begin{abstract}
Chronic Liver Damage (CLD) is the main cause of Hepatocellular carcinoma (HCC). Hepatitis C-Virus (HCV) infection resulting in inflammation of liver which may developed from acute to chronic that may develop into HCC. The aim of this work was to evaluate Apoptotic markers including (Transforming Growth Factor $\beta 1$ ) TGF- $\beta 1$ and CD90 and Annexin-V in patients with chronic liver disease (CLD) Fibrosis, HCC and healthy individuals. The present study included 51 patients with Fibrosis (F2-F4), 30 Hepatocellular Carcinoma (HCC) patients, in addition 40 normal healthy individuals were enrolled in this study as control group. AFP and CEA were estimated in all groups. TGF- $\beta 1$, CD90 and Annexin-V were estimated using Flow Cytometry technique. Results from this study revealed that there was high significance difference in APRI ratio, FIB-4 ratio between HCC, Fibrosis comparing with Control group ( $<<0.05)$, also there was high prevalence TGF- $\beta 1$ and CD90 in HCC patients comparing with both Fibrosis and healthy control group $(\mathrm{P}<0.005)$. Based on our observation in this study TGF- $\beta 1$ has diagnostic value importance in assessment of hepatocellular carcinoma. CD90 could be used as Cancer Stem Cell (CSC) biomarker in hepatocellular carcinoma patients. Chronic HCV resulting in increasing apoptosis..
\end{abstract}

Keywords: Hepatocellular carcinoma (HCC); Transforming growth Factor beta1 TGF- $\beta 1$; Alpha feto protein (AFP); Carcinoembryonic antigen (CEA).

\section{Introduction}

Chronic liver injury causes morbidity and mortality worldwide. Patients with chronic liver injury may progress from initial liver fibrosis to cirrhosis, which may developed into HCC [1-13]. The main aetiologies of chronic liver injury are chronic hepatitis $\mathrm{C}$ virus (HCV) and hepatitis B virus (HBV) infections [14]. In this study our subjects were divided into three different groups. Group I which including 51 Fibrosis classified according to METAVIR classification (F2-F4) patients, 42 males $(82.4 \%)$ and 9 females (17.6\%), their age ranged from 43-87 years with a mean of $59.9 \pm 10.1$ years. Group II which including 30 HCC patients, 23 males (76.7\%) and 7 females (23.3\%) and their age ranged from $43-74$ years with a mean of $57 \pm 8.81$ years. Group III which including 40 unrelated healthy adults with no liver diseases as a control group 28 males (70\%) and 12 females (30\%), and their age ranged from 20-51 years with a mean of $30.8 \pm 7.57$ years (Table 1 ). Our data was in agree with Hussein et al. [15], Hernandez-Castillo et al. [16] and Massoud et al. [17], who reported that the mean ages among HCC cases were $53.7 \pm 10.1,57.4 \pm 8.7$, and $55.2 \pm 8$ years, respectively (Figure 1 ). In the present study ALT activity was increased in Fibrosis (F2-F4) and HCC patients significantly compared with Healthy control group Mean \pm SD. were $59.9 \pm 36.7,56.3 \pm 35.7$ and $12.15 \pm 2.6$; respectively $(\mathrm{P}<0.005)$. Also, AST activity was increased in both Fibrosis(F2-F4) and HCC patients comparing with Healthy control group Mean SD. were 73.2 $\pm 35.6,70.1 \pm 28.3$ and $12.4 \pm 2.7$; respectively $(\mathrm{p}<0.005)$. Serum bilirubin was increased significantly in both HCC and Fibrosis patients comparing with Health control group with values $7.4 \pm 11.0,4.1 \pm 6.3$ and $0.3 \pm 0.18$; respectively $(\mathrm{p}<0.005)$. In our study albumin was decreased significantly in both HCC and Fibrosis patients comparing with Healthy control group with values $2.91 \pm 0.25,3.2 \pm 0.15$ and $4.3 \pm 0.43$; respectively $(\mathrm{p}<0.005)$ (Table 2$)$. 


\section{International Journal of Cell Science \& Molecular Biology}

Table 1: Individual characters in all studied groups.

\begin{tabular}{|c|c|c|c|}
\hline Groups & Group I & Group II & Group III \\
Characters & $\mathbf{N}=\mathbf{5 1}$ & $\mathbf{N = 3 0}$ & $\mathbf{N = 4 0}$ \\
\hline Age & $59.9 \pm 10.1$ & $57 \pm 8.81$ & $30.8 \pm 7.57$ \\
\hline Males & $42(82.4 \%)$ & $23(76.7 \%)$ & $28(70 \%)$ \\
\hline Females & $9(17.6 \%)$ & $7(23.3 \%)$ & $12(30 \%)$ \\
\hline
\end{tabular}

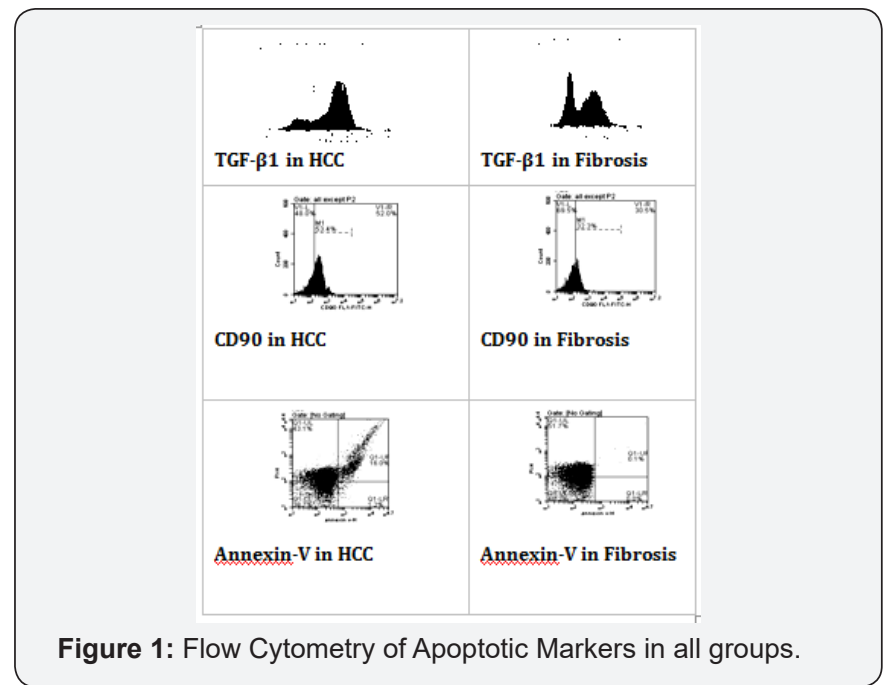

Table 2: Biochemical Parameters in all groups.

\begin{tabular}{|c|c|c|c|c|}
\hline $\begin{array}{c}\text { Biochemical } \\
\text { Parameters }\end{array}$ & $\begin{array}{c}\text { Group I } \\
\mathbf{N}=\mathbf{5 1}\end{array}$ & $\begin{array}{c}\text { Group II } \\
\mathbf{N}=\mathbf{3 0}\end{array}$ & $\begin{array}{c}\text { Group III } \\
\mathbf{N}=\mathbf{4 0}\end{array}$ & $\begin{array}{c}\mathbf{P}- \\
\text { value }\end{array}$ \\
\hline ALT $(\mathrm{U} / \mathrm{ml})$ & $59.9 \pm 36.7$ & $56.3 \pm 35.7$ & $12.15 \pm 2.6$ & $\mathrm{P}<0.005$ \\
\hline AST $(\mathrm{U} / \mathrm{ml})$ & $73.2 \pm 35.6$ & $70.1 \pm 28.3$ & $12.4 \pm 2.7$ & $\mathrm{P}<0.001$ \\
\hline Platelets $(\times 109)$ & $200.8 \pm 47.9$ & $153.8 \pm 54.5$ & $289.3 \pm 16.6$ & $\mathrm{P}=0.000$ \\
\hline $\begin{array}{c}\text { Bilirubin(mg/ } \\
\text { dl) }\end{array}$ & $4.1 \pm 6.3$ & $7.4 \pm 11.0$ & $0.3 \pm 0.18$ & $\mathrm{P}<0.005$ \\
\hline Albumin(g/dl) & $3.2 \pm 0.15$ & $2.91 \pm 0.25$ & $4.3 \pm 0.43$ & $\mathrm{P}<0.001$ \\
\hline AST/ALT ratio & $1.4 \pm 0.7$ & $1.5 \pm 0.58$ & $1.07 \pm 0.37$ & $\mathrm{P}<0.005$ \\
\hline APRI ratio & $1.3 \pm 1.3$ & $0.98 \pm 0.61$ & $0.1 \pm 0.2$ & $\mathrm{P}<0.001$ \\
\hline FIB-4 ratio & $4.2 \pm 3.6$ & $3.7 \pm 2.3$ & $0.38 \pm 0.13$ & $\mathrm{P}<0.005$ \\
\hline
\end{tabular}

Our data agree with Durazo et al. [18] who found that the mean value of AST activity in HCC was 3.5 times the upper limit of normal, and also with Okonkwo et al. [19] who found that the AST activity in HCC was 1.39 times the upper limit of normal. Serum ALT activity showed significant difference between the HCC group and the non-HCC group, which was in agreement with Durazo et al. [18].

Alpha-Fetoprotein (AFP) is a glycoprotein with molecular weight about $72 \mathrm{kDa}$. AFP normally synthesized during fetal life, first in the yolk sac and then in fetal liver [20]. In the present study tumor markers including both AFP and CEA were estimated using ELISA technique in all studied groups the mean values of AFP concentration in Fibrosis, HCC and healthy control were $25.08 \pm 22.2,423.3 \pm 4.7$ and $1.68 \pm 0.74$; respectively $(p<0.001)$. The mean value of CEA concentration in Fibrosis, HCC and healthy control were $2.64 \pm 0.66$ and $3.61 \pm 0.6$ and $1.26 \pm 0.13$; respectively, this was in agreement with Hussein et al. [15] who showed a significant elevation of serum AFP in HCC patients.

Transforming growth factor $\beta 1$ (TGF- $\beta 1$ ) is a multi-functional cytokine over expressed in HCC compared to that of chronic hepatitis C. It is suggested that TGF- $\beta 1$ may be associated with the malignant transformation of hepatocyte or the progression of HCV- associated HCC [21]. TGF- $\beta 1$ is suggested to play a role in development, growth or progression of hepatocellular carcinoma (HCC). In our study blood peripheral mononuclear cells TGF- $\beta 1$ was increased in HCC and Fibrosis patients comparing with Healthy control group with values Mean \pm SD. 78.6 \pm 9.0 , 55.5 \pm 18.0 and $12.07 \pm 1.62$ respectively $(\mathrm{p}<0.005)$. Table 3 this agree with number of studies suggest that activation of TGF- $\beta 1$ promote HCC development Hoshida et al. [22].

Table 3:TGF- $\beta 1$ in all groups.

\begin{tabular}{|c|c|c|c|c|}
\hline $\begin{array}{c}\text { Groups } \\
\text { TGF- } \boldsymbol{\beta} 1\end{array}$ & $\begin{array}{c}\text { Group I } \\
\text { (M1\%) }\end{array}$ & $\begin{array}{c}\text { Group II } \\
\mathbf{N}=\mathbf{3 0}\end{array}$ & $\begin{array}{c}\text { Group III } \\
\mathbf{N}=\mathbf{4 0}\end{array}$ & $\begin{array}{c}\text { P- } \\
\text { Valu }\end{array}$ \\
\hline Mean \pm SD & $55.5 \pm 18.0$ & $78.6 \pm 9.0$ & $12.07 \pm 1.62$ & \multirow{2}{*}{$\mathrm{P}<0.005$} \\
\hline Range & $24.3-87.0$ & $59.9-88.6$ & $10.1-15.3$ & \\
\hline
\end{tabular}

CD90 is glycophosphatidyl inositol -anchored protein expressed in many cells such as T-cells, thymocytes, neurons, endothelial cells and fibroblast. CD90 contributes an important regulator of cell to cell and cell to matrix interaction, apoptosis, adhesion, migration, cancer and fibrosis [23]. In our study blood peripheral mononuclear cells CD90 (M1\%) was increased significantly in HCC, Fibrosis patients comparing with Healthy control group and Mean \pm SD. were $46.29 \pm 4.0,39.66 \pm 5.49$ and $6.13 \pm 2.84$ respectively $(\mathrm{P}<0.005)$. This is in accordance with some previous studies on HCC cell lines and human samples, where CD90 was highly expressed in malignant hepatocytes and the presence of CD90+/CD44+ cells contributed to an aggressive phenotype with more frequent metastatic lesions in the lung Zhu et al. [24]. Our data was in agree with Bahnassy et al. who found that CD90 was significantly higher in the blood of HCC patients compared to those in the $\mathrm{CH}$ and control groups $(\mathrm{P}<0.001)$.

«Annexin-V» is $\mathrm{Ca}^{2+}$ dependent phospholipid-binding protein with high affinity for the membrane phospholipid phosphatidylserine (PS). Annexin-V can be conjugated to fluorochromes thus serves as a sensitive probe for flow cytometric analysis of cells undergoing apoptosis [25]. In the present study peripheral blood mononuclear cells(PBMC) Annexin V+/PI- which representing early apoptotic cells were increased significantly in both HCC and Fibrosis patients comparing with healthy individuals with Mean \pm SD. values $12.7 \pm 3.05$ and $14.1 \pm 4.0$ and $0.88 \pm 0.78$; respectively. In our study (PBMC) Annexin V-/PI+ which representing necrosis cells were increased significantly in both HCC and Fibrosis patients comparing with healthy control with values $9.7 \pm 3.91$ and 
$22.7 \pm 2.6$ and $0.7 \pm 1.36$; respectively $(\mathrm{p}<0.005)$. Also, (PBMC) Annexin V+/PI+ representing late apoptosis cells were increased significantly in both HCC and Fibrosis patients comparing with healthy control with values $25.3 \pm 4.54$ and $15.0 \pm 2.9$ and $0.07 \pm 0.06$; respectively $(\mathrm{p}<0.005)$.

\section{Conclusion}

Based on our observation in this study TGF- $\beta 1$ has diagnostic value in assessment of patients with chronic hepatitis-c virus and hepatocellular carcinoma. CD90 could be used as Cancer Stem Cell biomarker in HCC patients. In our study, liver function tests including (AST), (ALT), albumin and total bilirubin, were measured using standard methodologies Routine blood pictures including platelets counting were determined. The AST/ALT ratio, FIB-4 and APRI (AST/platelets count ratio index) Table 2. Tumor Markers including AFP and CEA were estimated using ELISA technique Table 4. Transforming Growth Factor- $\beta 1$, CD90 and Annexin-V were estimated using flow cytometry technique in all groups.

Table 4:AFP and CEA in all groups.

\begin{tabular}{|c|c|c|c|c|}
\hline $\begin{array}{c}\text { Tumor } \\
\text { Markers }\end{array}$ & $\begin{array}{c}\text { Group } \\
\text { I } \\
\mathbf{N}=\mathbf{5 1} \\
\text { Mean } \pm \text { SD. }\end{array}$ & $\begin{array}{c}\text { Group } \\
\text { II } \\
\mathbf{N = 3 0} \\
\text { Mean } \pm \text { SD. }\end{array}$ & $\begin{array}{c}\text { Group III } \\
\mathbf{N}=\mathbf{4 0} \\
\text { Mean } \pm \text { SD. }\end{array}$ & $\begin{array}{c}\text { P } \\
\text { Value }\end{array}$ \\
\hline AFP (ng/ & $\begin{array}{c}25.08 \\
\mathrm{ml})\end{array}$ & $\begin{array}{c}423.3 \\
\pm 2.2\end{array}$ & $\begin{array}{c}1.68 \\
\pm 0.74\end{array}$ & $\mathrm{P}<0.005$ \\
\hline $\mathrm{CEA}(\mu \mathrm{g} / \mathrm{l})$ & $\begin{array}{c}2.64 \\
\pm 0.66\end{array}$ & $\begin{array}{c}3.61 \\
\pm 0.6\end{array}$ & $\begin{array}{c}1.26 \\
\pm 0.13\end{array}$ & $\mathrm{P}<0.005$ \\
\hline
\end{tabular}

Table 5:CD90 Flow Cytometry in all groups.

\begin{tabular}{|c|c|c|c|c|}
\hline Annexin -V & Group I & Group II & Group III & P value \\
\hline Viable Cells & $47.4 \pm 3.07$ & $51.0 \pm 6.23$ & $98.0 \pm 2.04$ & $\mathrm{P}<0.001$ \\
\hline $\begin{array}{c}\text { Early } \\
\text { Apoptosis }\end{array}$ & $14.1 \pm 4.0$ & $12.7 \pm 3.05$ & $0.88 \pm 0.78$ & $\mathrm{P}<0.005$ \\
\hline $\begin{array}{c}\text { Late } \\
\text { Apoptosis }\end{array}$ & $15.0 \pm 2.9$ & $25.3 \pm 4.54$ & $0.07 \pm 0.06$ & $\mathrm{P}<0.001$ \\
\hline Necrosis & $22.7 \pm 2.6$ & $9.7 \pm 3.91$ & $0.7 \pm 1.36$ & $\mathrm{P}<0.001$ \\
\hline
\end{tabular}

\section{Discussion}

Chronic liver injury causes morbidity and mortality worldwide. Patients with chronic liver injury may progress from initial liver fibrosis to cirrhosis, which may develop into HCC. The main aetiologies of chronic liver injury are chronic hepatitis $\mathrm{C}$ virus (HCV) and hepatitis B virus (HBV) infections [14]. In this study our subjects were divided into three different groups. Group I which including 51 Fibrosis classified according to METAVIR classification (F2-F4) patients, 42 males (82.4\%) and 9 females (17.6\%), their age ranged from 43-87 years with a mean of $59.9 \pm 10.1$ years. Group II which including 30 HCC patients, 23 males $(76.7 \%)$ and 7 females $(23.3 \%)$ and their age ranged from $43-74$ years with a mean of $57 \pm 8.81$ years. Group III which including 40 unrelated healthy adults with no liver diseases as a control group 28 males (70\%) and 12 females (30\%), and their age ranged from 20-51 years with a mean of $30.8 \pm 7.57$ years (Table 1 ). Our data was in agree with
Hussein et al. [15], Hernandez-Castillo et al. [16], and Massoud et al. [17], who reported that the mean ages among HCC cases were $53.7 \pm 10.1,57.4 \pm 8.7$, and $55.2 \pm 8$ years, respectively. In the present study ALT activity was increased in Fibrosis(F2-F4) and HCC patients significantly compared with Healthy control group Mean \pm SD. were $59.9 \pm 36.7,56.3 \pm 35.7$ and 12.15 \pm 2.6; respectively $(\mathrm{P}<0.005)$.

Also, AST activity was increased in both Fibrosis (F2-F4) and HCC patients comparing with Healthy control group Mean SD. Were $73.2 \pm 35.6,70.1 \pm 28.3$ and $12.4 \pm 2.7$; respectively $(\mathrm{p}<0.005)$. Serum bilirubin was increased significantly in both HCC and Fibrosis patients comparing with Health control group with values $7.4 \pm 11.0,4.1 \pm 6.3$ and $0.3 \pm 0.18$; respectively ( $\mathrm{p}<$ $0.005)$. In our study albumin was decreased significantly in both HCC and Fibrosis patients comparing with Healthy control group with values $2.91 \pm 0.25,3.2 \pm 0.15$ and $4.3 \pm 0.43$; respectively $(\mathrm{p}<0.005)$ (Table 2).

Our data agree with Durazo et al. [18] who found that the mean value of AST activity in HCC was 3.5 times the upper limit of normal, and also with Okonkwo et al. [19] who found that the AST activity in HCC was 1.39 times the upper limit of normal. Serum ALT activity showed significant difference between the HCC group and the non-HCC group, which was in agreement with Durazo et al. [18].

Alpha-Fetoprotein (AFP) is a glycoprotein with molecular weight about $72 \mathrm{kDa}$. AFP normally synthesized during fetal life, first in the yolk sac and then in fetal liver [20]. In the present study tumor markers including both AFP and CEA were estimated using ELISA technique in all studied groups the mean values of AFP concentration in Fibrosis, HCC and healthy control were $25.08 \pm 22.2,423.3 \pm 4.7$ and $1.68 \pm 0.74$; respectively $(\mathrm{p}<0.001)$. The mean value of CEA concentration in Fibrosis, HCC and healthy control were $2.64 \pm 0.66$ and $3.61 \pm 0.6$ and $1.26 \pm 0.13$; respectively, this was in agreement with Hussein et al. [15] who showed a significant elevation of serum AFP in HCC patients.

Transforming growth factor $\beta 1$ (TGF- $\beta 1$ ) is a multi-functional cytokine over expressed in HCC compared to that of chronic hepatitis C. It is suggested that TGF- $\beta 1$ may be associated with the malignant transformation of hepatocyte or the progression of HCV- associated HCC [21]. TGF- $\beta 1$ is suggested to play a role in development, growth or progression of hepatocellular carcinoma (HCC). In our study blood peripheral mononuclear cells TGF- $\beta 1$ was increased in HCC and Fibrosis patients comparing with Healthy control group with values Mean \pm SD. 78.6 \pm 9.0 , 55.5 \pm 18.0 and $12.07 \pm 1.62$ respectively $(\mathrm{p}<0.005)$. Table $4 \& 5$ this agree with number of studies suggest that activation of TGF- $\beta 1$ promote HCC development Hoshida et al. [22].

CD90 is glycophosphatidyl inositol -anchored protein expressed in many cells such as T-cells, thymocytes, neurons, endothelial cells and fibroblast. CD90 contributes an important regulator of cell to cell and cell to matrix interaction, apoptosis, adhesion, migration, cancer and fibrosis [23]. In our study 
blood peripheral mononuclear cells CD90 (M1\%) was increased significantly in HCC, Fibrosis patients comparing with Healthy control group and Mean \pm SD. were 46.29 $\pm 4.0,39.66 \pm 5.49$ and $6.13 \pm 2.84$ respectively $(\mathrm{P}<0.005)$. This is in accordance with some previous studies on HCC cell lines and human samples, where CD90 was highly expressed in malignant hepatocytes and the presence of CD90+/CD44+ cells contributed to an aggressive phenotype with more frequent metastatic lesions in the lung Zhu et al. [24]. Our data was in agree with Bahnassy et al. who found that CD90 was significantly higher in the blood of HCC patients compared to those in the $\mathrm{CH}$ and control groups $(\mathrm{P}<0.001)$.

«Annexin-V» is $\mathrm{Ca} 2+$ dependent phospholipid-binding protein with high affinity for the membrane phospholipid phosphatidyl serine (PS). Annexin-V can be conjugated to fluoro chromes thus serves as a sensitive probe for flow cytometric analysis of cells undergoing apoptosis [25]. In the present study peripheral blood mononuclear cells(PBMC) Annexin V+/ PI- which representing early apoptotic cells were increased significantly in both HCC and Fibrosis patients comparing with healthy individuals with Mean \pm SD. values $12.7 \pm 3.05$ and $14.1 \pm 4.0$ and $0.88 \pm 0.78$; respectively. In our study (PBMC) Annexin V-/PI+ which representing necrosis cells were increased significantly in both HCC and Fibrosis patients comparing with healthy control with values $9.7 \pm 3.91$ and $22.7 \pm 2.6$ and $0.7 \pm 1.36$; respectively $(\mathrm{p}<0.005)$. Also, (PBMC) Annexin $\mathrm{V}+/ \mathrm{PI}+$ representing late apoptosis cells were increased significantly in both HCC and Fibrosis patients comparing with healthy control with values $25.3 \pm 4.54$ and $15.0 \pm 2.9$ and $0.07 \pm 0.06$; respectively $(\mathrm{p}<0.005)$.

\section{Conclusion}

Based on our observation in this study TGF- $\beta 1$ has diagnostic value in assessment of patients with chronic hepatitis-c virus and hepatocellular carcinoma. CD90 could be used as Cancer Stem Cell biomarker in HCC patients.

\section{Acknowledgment}

We would like to express our gratitude to members from the Gastroenterology Center in Mansoura for their collaboration during the study.

\section{References}

1. Kandeel A, Genedy M, El-Refai S, Funk LA, Fontanet A, et al. (2017) The prevalence of hepatitis C virus infection in Egypt 2015: implications for future policy on prevention and treatment. Liver Int 37(1): 45-53.

2. Roncalli M, Park YN, di Tommaso L (2010) Histopathological classification of hepatocellular carcinoma. Dig Liver Dis 42(Suppl 3): S228-S234.

3. Marrero J, Feng Z, Wang Y, Nguyen M, Befeler A, et al. (2009) Alfafeto protein, des-gamma carboxy prothrombin, and lectin-bound alphafeto protein in early hepatocellular carcinoma. Gastroenterology 137(1): 110-118.

4. Hansen J, Snyder J, Miller E, Vandevoorde P, Miller N, et al. (1974) Carcinoembryonic antigen (CEA) assay: a laboratory adjunct in the diagnosis and management of cancer. Hum Pathol 5(2): 139-147.
5. Karkampouna S, Ten Dijke P, Dooley S, Julio MK (2012) TGF-beta signaling in liver regeneration. Curr Pharm Des 18(27): 4103-4113.

6. Faubion WA, Gores GJ (1999) Death receptors in liver biology and pathobiology. Hepatology 29(1): 1-4.

7. Reitman, Frankel (1957) A colorimetric method for the determination of serum glutamic oxalacetic and glutamic pyruvic transaminases. Am J Clin Pathol 28(1): 56-63.

8. Perry B, Doumas BT, Buffone G, Glick M, Oy CN, et al. (1986) Measurement of total bilirubin by use of bilirubin oxidase. Clin Chem 32(2): 329-332.

9. Doumas BT, Watson WA, Biggs HG (1971) Albumin standards and the measurement of serum albumin with bromocresol green. Clin Chim 258(1): 31-30.

10. Wai CT, Greenson JK, Fontana RJ, Kalbfleisch JD, Marrero JA, et al. (2003) A simple noninvasive index can predict both significant fibrosis and cirrhosis in patients with chronic hepatitis C. Hepatology 38(2): 518-526.

11. Sterling RK, Lissen E, Clumeck N, Sola R, Cassia Correa M, et al. (2006) Development of a simple noninvasive index to predict significant fibrosis in patients with HIV/HCV coinfection. Hepatology 43(6): 1317-1325.

12. Silver K, Gold P, Feder S, Freedman O, Shuster J (1973) Radioimmunoassay for Human Alpha-1 Fetoprotein. Proc Natl Acad Sci USA 70(2): 526-530.

13. Hansen J, LaFontaine G, Newman S, Schwartz K, Malkin A, et al. (1989) Solving the problem of antibody interference in commercial "sandwich"-type immunoassays of carcinoembryonic antigen. Clin Chem 35(1): 146-151.

14. Venook AP, Papandreou C, Furuse J, Guevara LL (2010) The incidence and epidemiology of hepatocellular carcinoma: a global and regional perspective. Oncologist 15(Suppl 4): 5-13.

15. Hussein MM, Ibrahim AA, Khattab NA, EL Fouly RF, EL-Fouly NF (2010) Serum transforming growth factor beta1 in hepatitis c virus related chronic liver disease and hepatocellular carcinoma patients. Med J Cairo Univ 78: 279-286.

16. Hernandez-Castillo E, Mondragon-Sanchwz R, Garduno-Lopez AL, Gómez-Gómez E, Ruiz-Molina JM, et al. (2005) Hepatocellular carcinoma in the youth. A comparative analysis with hepatocellular carcinoma in adulthood. J Gastroenterol Hepatol 52(63): 903-907.

17. Massoud A, Reda M, Shaker M (2006) Detection of hepatitis B and C viruses in hepatocellular carcinoma tissue. In: Liver International, $24^{\text {th }}$ Biennial Meeting of the International Association for the study of the Liver (IASL) in collaboration with the African Association for the Study of Liver Diseases (AFASLD) 26: 67-77.

18. Durazo FA, Blatt LM, Corey WG, Lin JH, Han S, et al. (2008) Des-gammacarboxy-prothrombin, alpha-fetoprotein and AFP-L3 in patients with chronic hepatitis, cirrhosis and hepatocellular carcinoma. J Gastroenterol Hepatol 23(10): 1541-1548.

19. Okonkwo UC, Nwosu MN, Nnadozie OJ, Mamah VV, Nsoedo CW (2011) Is liver function test of any diagnostic relevance in patients presenting with hepatocellular carcinoma. Orient J Med 23: 1-4.

20. Mizejewski GJ (2001) Alpha-fetoprotein structure and function: relevance to isoforms, epitopes, and conformational variants. Exp Biol Med (Maywood) 226(5): 377-408.

21. Mayoral R, Valverde MA, Izquierdo LC, Rodríguez GA, Boscá L, et al. (2010) Impairment of Transforming Growth Factor $B$ Signaling in Caveolin-1-deficient Hepatocytes. Role in liver regeneration. J Biol Chem 285(6): 3633-3642.

22. Hoshida Y, Nijman SM, Kobayashi M, Chan JA, Brunet JP, et al. (2009) Integrative transcriptome analysis reveals common molecular 
subclasses of human hepatocellular carcinoma. Cancer Res 69(18): 7385-7392.

23. Herrera MB, Bruno S, Buttiglieri S, Tetta C, Gatti S, et al. (2006) Isolation and characterization of a stem cell population from adult human liver Stem Cells 24: 2840-2850.

24. Zhu F, Zheng CJ, Han LY, Xie B, Jia J, et al. (2008) Trends in the exploration of anticancer targets and strategies in enhancing the efficacy of drug targeting. Curr Mol Pharmacol 1(3): 213-232.

25. Casciola-Rosen L, Rosen A, Petri M, Schlissel M (1996) Surface blebs on apoptotic cells are sites of enhanced procoagulant activity: implications for coagulation events and antigenic spread in systemic lupus erythematosus. Proc Nat Acad Sci USA 93(4): 1624-1629.

\section{Your next submission with Juniper Publishers} will reach you the below assets

- Quality Editorial service

- Swift Peer Review

- Reprints availability

- E-prints Service

- Manuscript Podcast for convenient understanding

- Global attainment for your research

- Manuscript accessibility in different formats ( Pdf, E-pub, Full Text, Audio)

- Unceasing customer service

Track the below URL for one-step submission https://juniperpublishers.com/online-submission.php 